\title{
The Incidence of Seizures after Rehydration of Hypernatremic Rabbits with Intravenous or ad Libitum Oral Fluids
}

\author{
GWENDOLYN R. HOGAN, (26) PHILIP R. DODGE, SHEILA R. GILL, LARRY K. PICKERING, \\ AND SUSAN MASTER \\ Department of Neurology, Harvard Medical School, Neurology and Children's Services and the Joseph P. \\ Kennedy, Jr., Memorial Laboratories, Massachusetts General Hospital, Boston, Massachusetts, USA
}

\begin{abstract}
Summary
Hypernatremic dehydration (mean plasma sodium, $184 \mathrm{mEq}$ / L) was produced over a 3-5 d period in 71 rabbits. The dehydrated animals were divided into groups and rehydrated by intravenous $(4,6$, and $8 \mathrm{~h}$ duration) or oral ( 4 and $24 \mathrm{~h}$ duration) solutions in amounts calculated to return plasma $\mathrm{Na}$ to $140 \mathrm{mEq} /$ L. Plasma was obtained serially from each animal for electrolyte and osmolality determinations during dehydration and rehydration. Samples of brain hemisphere and cortex were obtained for chemical analysis from every animal immediately after death.

The incidence of seizures was significantly less $(P<0.025)$ in rabbits rehydrated orally when compared with rabbits rehydrated by the intravenous route. Brain water content was significantly greater in rabbits rehydrated intravenously when compared with normal rabbits and rabbits rehydrated orally. In addition, the amount of brain water was greater in rabbits with seizures when compared with those which did not have seizure manifestations. The mechanism underlying the significant reduction in seizures when the animals were rehydrated orally may relate to an integration of drinking behavior with rehydration status. Administration of oral fluids may provide an effective method of therapy for some patients with hypernatremic dehydration.
\end{abstract}

\section{$\mathrm{D} / \mathrm{W}$, dextrose in water}

\section{Abbreviation}

Hypernatremic animals and man may convulse after sufficient water has been administered intravenously to return plasma sodium concentrations to normal $(10,12,22)$. If hypernatremia is untreated or treated late in the course, a high incidence of morbidity and/or mortality occurs. Most studies of hypernatremia in the past have evaluated intravenous rehydration using various solutions and have shown that the incidence of seizures varies directly with the rate of intravenous rehydration $(2,4,10$ $12,22)$. Oral therapy has been used successfully in rehydrating both children and adults who were dehydrated due to diarrheal disease $(6-8,16,20)$. Although most of these patients had isotonic dehydration, a few experienced hypernatremic dehydration and were successfully treated (8). This study was undertaken to define the physiologic, biochemical, and clinical alterations which accompany various modes of intravenous and oral rehydration of hypernatremic rabbits.

\section{MATERIALS AND METHODS}

Production of hypernatremic dehydration. Hypernatremic dehydration was produced gradually over a 3-5-d period in New
Zealand white male rabbits (weight, $2-3.5 \mathrm{~kg}$ ) fed $1 \mathrm{M}$ sodium chloride solution by nasogastric tube five times daily in amounts calculated to raise the serum sodium concentration over 3-5 d (10). The volume required varied between $45-80 \mathrm{ml} / \mathrm{d}$. Food in the form of rabbit pellets was available during the course of the study. Body weight, hematocrit, plasma $\mathrm{Na}, \mathrm{K}$, and osmolality were determined before dehydration, $48 \mathrm{~h}$ after saline feedings were begun, and daily thereafter. In addition, blood for calcium, magnesium, chloride, and blood urea nitrogen was obtained from 48 animals. Blood volumes were determined in nine animals by the isotope dilution technique using serum $\left[{ }^{131} \mathrm{I}\right]$ albumin (23) $(0.5 \mu \mathrm{Ci}$ in $0.5 \mathrm{ml})$.

The daily dose of saline used to produce hypernatremic dehydration was adjusted to achieve a plasma $\mathrm{Na}$ of greater than $175 \mathrm{mEq} / \mathrm{L}$ (mean, $184 \mathrm{mEq} / \mathrm{L}$; range, 175-204). Immediately before rehydration, all initial blood studies were repeated.

Rehydration. The hypernatremic animals were divided into the following groups:

Group $1 a$, intravenous rehydration with $2.5 \% \mathrm{D} / \mathrm{W}$ over $4 \mathrm{~h}$ with a post-rehydration period of $4 \mathrm{~h}$ before sacrifice (10).

Group $1 b$, intravenous rehydration with $2.5 \% \mathrm{D} / \mathrm{W}$ over $4 \mathrm{~h}$ followed immediately by sacrifice.

Group 2, intravenous rehydration with $2.5 \% \mathrm{D} / \mathrm{W}$ over $6 \mathrm{~h}$ with a post-rehydration observation period of $4 \mathrm{~h}$.

Group 3, intravenous rehydration with $2.5 \% \mathrm{D} / \mathrm{W}$ over $8 \mathrm{~h}$ with a post-rehydration observation period of $4 \mathrm{~h}$.

Group $4 a$, ad libitum oral rehydration with water over $24 \mathrm{~h}$.

Group $4 b$, ad libitum oral rehydration with water over $4 \mathrm{~h}$ followed by sacrifice.

Intravenous rehydration using $2.5 \% \mathrm{D} / \mathrm{W}$ in amounts calculated to return the plasma $\mathrm{Na}$ to $140 \mathrm{mEq} / \mathrm{L}$ was maintained at a constant rate for 4,6 , or $8 \mathrm{~h}$. The amount infused varied between $85-110 \mathrm{ml} / \mathrm{h}$. Blood samples were drawn from 27 animals at 2$h$ intervals. At the end of rehydration and before sacrifice, blood samples were obtained from all animals. If seizures occurred during the rehydration or subsequent observation period, the animal was observed for $20 \mathrm{~min}$. Final blood samples were then taken, and the animal was weighed and sacrificed.

Samples of brain and muscle were obtained for chemical analysis from every animal immediately after death. Autopsies were performed on all rabbits at which time the volume and electrolyte concentration of peritoneal fluid and gastrointestinal contents were measured. In addition, wet weights of lungs, liver, and kidneys were obtained. Brains were examined grossly and histologically for evidence of hemorrhage.

In Group 4, rehydration was accomplished by allowing the animals free access to water. Water intake was carefully measured and tabulated every $5 \mathrm{~min}$ during the first $30 \mathrm{~min}$ of rehydration and every 15 min thereafter, for a period of $24 \mathrm{~h}$ in Group $4 \mathrm{a}$ 
and $4 \mathrm{~h}$ in Group 4b. During this time, the animals were observed constantly. Hematocrit, plasma $\mathrm{Na}, \mathrm{K}$, and osmolality were measured at $4,8,12$, and $24 \mathrm{~h}$ after beginning the rehydration period. In one animal with convulsions in Group $4 \mathrm{a}$, these tests also were obtained at the time of the first seizure. All animals in Group $4 \mathrm{a}$ were weighed and sacrificed $24 \mathrm{~h}$ after first access to water.

Statistical analysis. Statistical evaluation was performed by chi-square analysis with Yates correction and $t$ test analysis.

\section{RESULTS}

Changes in body weight and hematocrit values. The mean weight loss of rabbits $48 \mathrm{~h}$ after saline feedings were begun was $408 \pm 115 \mathrm{~g}$ or $16.4 \%$ of the weight immediately before dehydration. At the onset of rehydration, the mean weight loss was $488 \pm 124 \mathrm{~g}(19.6 \%)$. At the time of sacrifice, animals with seizures had gained $16.5 \pm 4.1 \%$ and those not having seizures had gained $13.5 \pm 3.5 \%$ of their dehydrated weights. These values were not significantly different. A decrease in hematocrit values of $7 \pm 1.1 \%$ occurred $120 \mathrm{~h}$ after saline feedings were begun. There were no significant differences in hematocrit values among the rehydration groups. The changes in hematocrit values could not be explained by volume of blood removed or sequestration of blood in the spleen or other tissues.

Plasma electrolyte and osmolality concentrations. Table 1 contains plasma electrolyte and osmolality concentrations of the different groups of animals and the incidence and severity of seizure activity. Plasma $\mathrm{Na}$ and osmolal concentrations at maximal dehydration were significantly greater $(P<0.001)$ in all groups when compared to normal, end rehydration, and final values. Plasma Na values (Fig. 1) were not significantly different in groups $1 \mathrm{a}$ and $4 \mathrm{a}$, except at the end of rehydration in Group la $(4 \mathrm{~h})$ when the plasma $\mathrm{Na}$ value was significantly less $(P<$ 0.025 ) than that in Group 4a. The plasma osmolality values (Fig. 2) were similar in Groups $1 \mathrm{a}$ and $4 \mathrm{a}$ at all times, except $2 \mathrm{~h}$ into rehydration when it was significantly elevated $(P<0.01)$ in Group 1a. This increase in plasma osmolality cannot be ex-

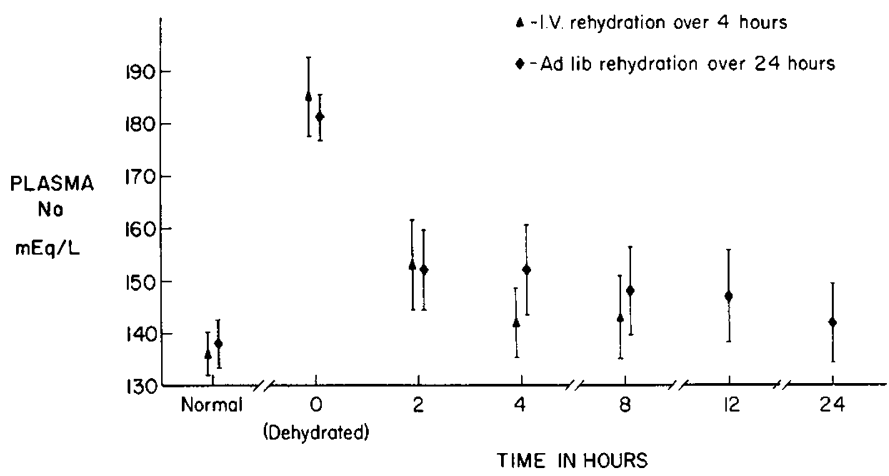

Fig. 1. Comparison of plasma sodium levels between animals rehydrated intravenously over $4 \mathrm{~h}$ (Group la) and those allowed to rehydrate ad libitum (Group 4b). Plasma sodium values are not significantly different except at the end of rehydration $(4 \mathrm{~h})$ when rabbits rehydrated ad libitum had significantly $(P<0.01)$ greater values than those rehydrated intravenously over $4 \mathrm{~h}$. Values expressed as mean $\pm \mathrm{SD}$.

Table 1. The relationship between the rate and route of rehydration of hypernatremic rabbits and the development of seizures and to plasma electrolyte osmolality values*

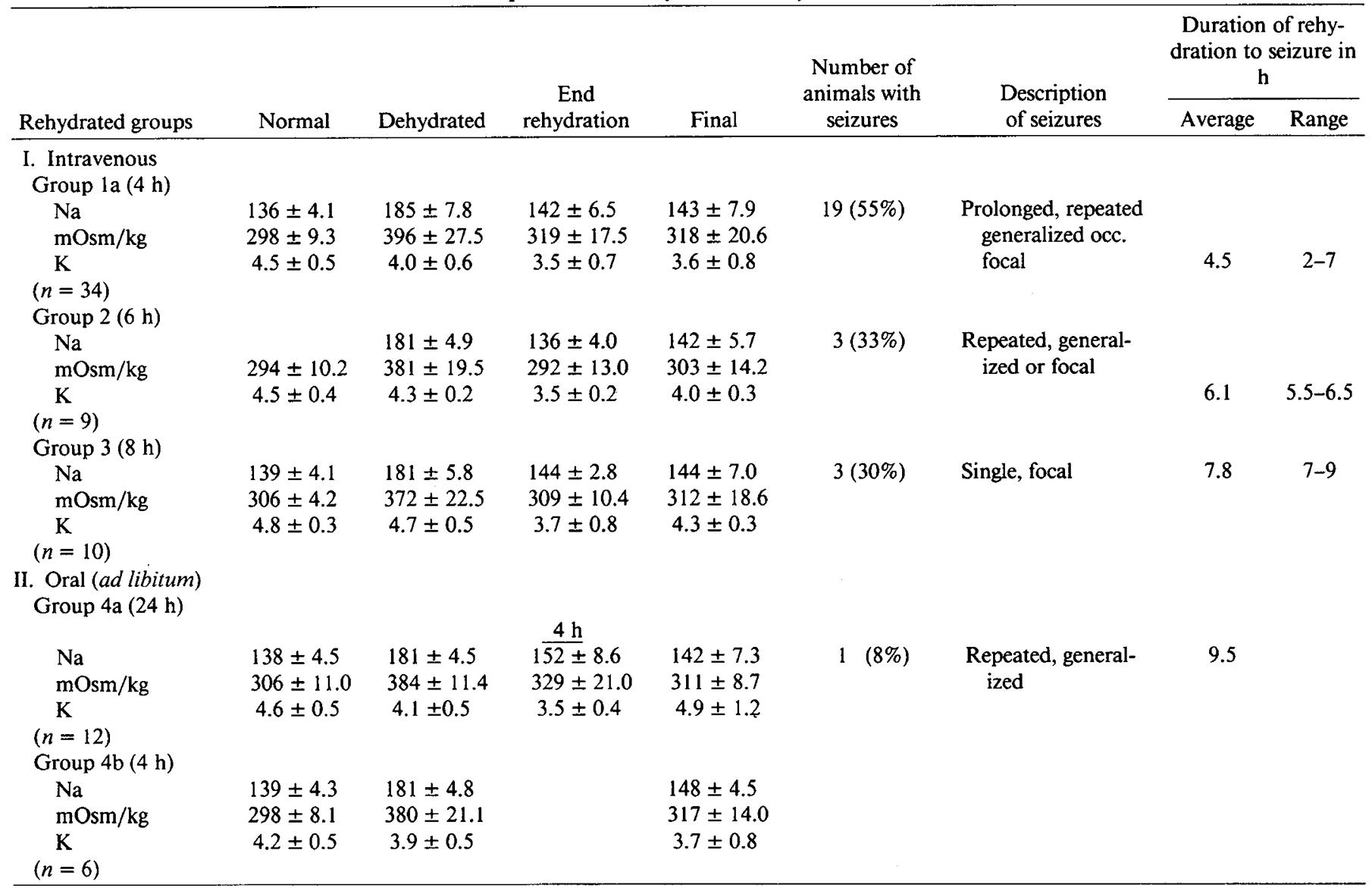

* Values are expressed as mean $\pm 1 \mathrm{SD}$. Na, sodium; $\mathrm{K}$, potassium, and all values are expressed as $\mathrm{mEq} / \mathrm{L}$. 


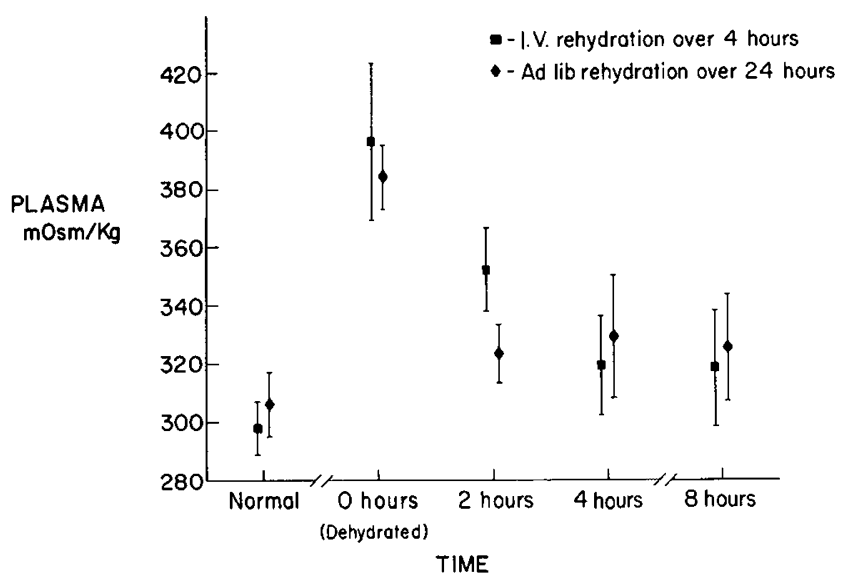

Fig. 2. Comparison of plasma osmolality between animals rehydrated intravenously over $4 \mathrm{~h}$ (Group la) and those allowed to rehydrate ad libitum (Group $4 \mathrm{~b}$ ). The values for plasma osmolality were significantly $(P<0.01)$ greater at $2 \mathrm{~h}$ in rabbits rehydrated intravenously over $4 \mathrm{~h}$ when compared with those rehydrated ad libitum. Values expressed as mean $\pm \mathrm{SD}$. plained on the basis of plasma sodium because the values were similar.

Oral rehydration. Animals allowed to rehydrate themselves by ad libitum oral intake over a 24 -h period (Group 4a) had a significantly lower $(P<0.025)$ incidence of seizures than animals rehydrated intravenously. There was no significant difference among intravenously rehydrated groups of rabbits in the incidence of seizures; however, there was a trend towards fewer seizures with longer periods of rehydration. The pattern of oral water intake and its correlation with plasma sodium is outlined in Figure 3. The average amount taken in each half-hour period is plotted from the beginning of rehydration to the end of the 24-h period. A large volume of water was consumed within the first $2 \mathrm{~h}(210 \mathrm{ml})$ after which the average rate of ingestion decreased. This resulted in an accelerated fall in plasma tonicity as compared with that of animals rehydrated intravenously (Fig. 2). Plasma sodium decreased from a mean of $181 \pm 4.3 \mathrm{mEq} / \mathrm{l}$ in the dehydrated state to $152 \pm 8.6 \mathrm{mEq} / \mathrm{L}$ within the first $2 \mathrm{~h}$. Plasma K concentrations (Table 1) were comparable between the two groups.

One rabbit in Group 4a with an unusual drinking pattern developed seizures (Fig. 4). The rabbit drank during 11 of the first 19 half-hour intervals, decreasing his plasma $\mathrm{Na}$ concentra-

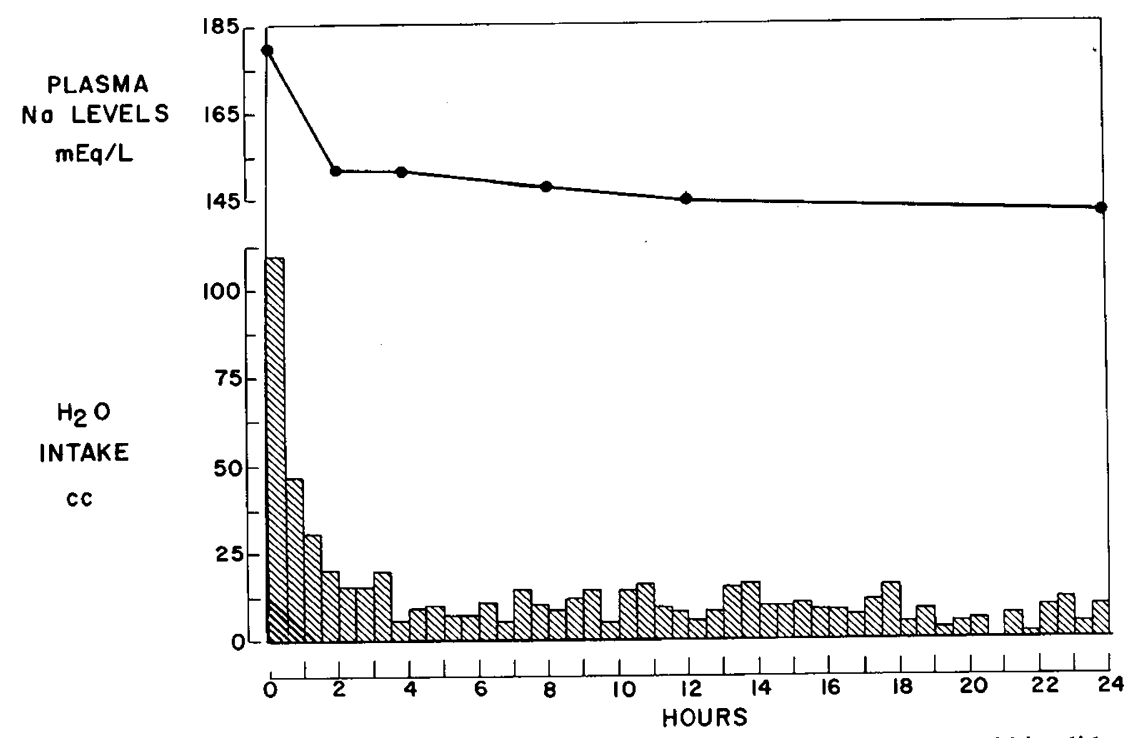

Fig. 3. The average drinking pattern during ad libitum rehydration of 10 rabbits in Group $4 \mathrm{a}$. These rabbits did not have seizures. During the first $2 \mathrm{~h}$ the rabbits ingested $225 \pm 28 \mathrm{ml}$ of water. Over the subsequent $8 \mathrm{~h}$ they ingested $153 \pm 30 \mathrm{ml}$.

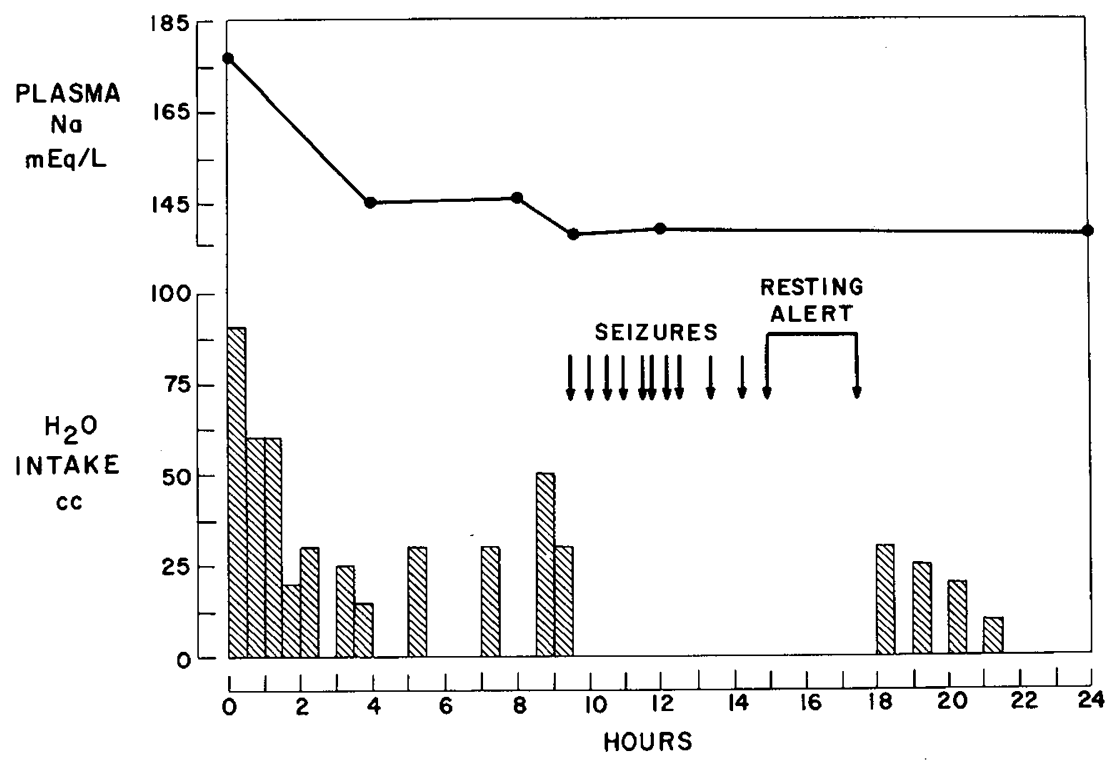

Fig. 4. The drinking pattern of the single rabbit with seizures rehydrated ad libitum. During the initial $2 \mathrm{~h}$ he ingested $228 \mathrm{ml}$ of water; however, he ingested an amount $(221 \mathrm{ml})$ over the subsequent $8 \mathrm{~h}$ that was greater than in rabbits which did not have seizures. 
tion to $145 \mathrm{mEq} / \mathrm{L}$ at $4 \mathrm{~h}$. During the initial $2 \mathrm{~h}$ he ingested a volume of water similar to that ingested by rabbits which did not develop seizures $(228 \mathrm{ml}$ versus $225 \pm 28 \mathrm{ml})$; however, he persisted in ingesting a relatively large amount of water $(221 \mathrm{ml}$ versus $153 \pm 30 \mathrm{ml}$ ) over the subsequent $8 \mathrm{~h}$. The first seizure occurred after $10 \mathrm{~h}$ into rehydration when the plasma $\mathrm{Na}$ was $136 \mathrm{mEq} / \mathrm{L}$. At this point, the animal stopped drinking and did not resume water intake until $8 \frac{1}{2} \mathrm{~h}$ later. During this time he was alert and physically able to secure water.

Comparison of oral intake of water by each animal with the calculated intravenous dose required to lower the plasma sodium to normal shows that only three of the animals failed to drink as much water during the first $2 \mathrm{~h}$ as they would have been given intravenously during that period of time. Two animals approached their calculated total rehydrating dose by $1 \mathrm{~h}$ and nine animals had exceeded their rehydrating dose (mean $164 \%$, range $104-227 \%$ ) at the end of $2 \mathrm{~h}$, yet no seizure had occurred. The one animal manifesting seizure activity came close to rehydrating himself in $4 \mathrm{~h}$ but continued to drink a volume of water which exceeded that ingested by rabbits that did not develop seizure activity. Intake during the 24 -h period varied from $73.0-184.7 \%$ (mean 116\%) of water calculated to return the plasma sodium to normal. Only three animals did not complete their rehydration according to our calculation of volume needed to correct hypertonicity plus daily maintenance.

Blood volumes. Blood volumes obtained before dehydration in 9 rabbits averaged $5.7 \%$ of body weight. After dehydration and $4 \mathrm{~h}$ of intravenous or oral rehydration, the mean blood volume in the same animals was $6.4 \%$ of body weight.

Brain tissue evaluation. Water and electrolyte contents in brain tissue of all groups are recorded in Table 2. The $P$ values indicate significance when compared with values obtained from normal rabbits. There was a significant increase in cortex $(P<0.02)$ and hemisphere $(P<0.001)$ water content in animals with seizures rehydrated over $4 \mathrm{~h}$. No significant difference was noted in water content in any other group when compared with normal except in rabbits with seizures in Group 2, who had a significantly greater $(P<0.05)$ water content in cortex. In all groups, the amount of water in cortex of animals that had seizures was greater than in cortex of animals without seizures.

Autopsy findings. The weights of lungs, liver, and kidneys obtained from animals in Group $1 \mathrm{~b}$ were similar to normal control rabbits. Group 4b animals sacrificed after 4-h ad libitum rehydration also demonstrated no accumulation of fluid in the bowel or excess organ weights. None of the brains showed evidence of hemorrhage upon gross inspection and no hemorrhage was observed in 20 brains, which were examined histologically. There was no significant change in the serum calcium or magnesium concentrations in any animal studies.

\section{DISCUSSION}

The hypernatremic state cannot be corrected too quickly because of the possibility of inducing cerebral swelling (relative water intoxication) $(10,22)$. This study was undertaken to evaluate various methods of rehydrating hypernatremic rabbits. The electrolyte content of brain tissue from animals rehydrated either intravenously or orally revealed no significant difference between these groups in the levels of sodium. Potassium content was significantly elevated in the cortex of those animals without

Table 2. Cerebral cortex and hemisphere water, sodium, potassium, and chloride content under normal and experimental conditions*

\begin{tabular}{|c|c|c|c|c|c|c|c|c|}
\hline \multirow[t]{2}{*}{ Group } & \multicolumn{2}{|c|}{ Water content } & \multicolumn{2}{|c|}{ Sodium } & \multicolumn{2}{|c|}{ Potassium } & \multicolumn{2}{|c|}{ Chloride } \\
\hline & Cortext & Hemisphere & Cortext & Hemisphere & Cortex & Hemisphere & Cortex & Hemisphere \\
\hline Normal rabbits & $\begin{array}{c}442.6 \pm 14.0 \\
(22)\end{array}$ & $\begin{array}{c}401.6 \pm 22.9 \\
(22)\end{array}$ & $\begin{array}{c}22.6 \pm 2.7 \\
(20)\end{array}$ & $\begin{array}{c}18.5 \pm 3.2 \\
(20)\end{array}$ & $\begin{array}{c}42.4 \pm 2.7 \\
(20)\end{array}$ & $\begin{array}{c}32.9 \pm 3.7 \\
(20)\end{array}$ & $\begin{array}{c}17.3 \pm 0.9 \\
(20)\end{array}$ & $\begin{array}{c}15.5 \pm 1.6 \\
(20)\end{array}$ \\
\hline Intravenous Group la & $\begin{array}{l}454.7 \pm 21.8 \\
(33) \dagger\end{array}$ & $\begin{array}{l}425.9 \pm 22.8 \\
(32) \S\end{array}$ & $\begin{array}{l}22.5 \pm 2.2 \\
(31)\end{array}$ & $\begin{array}{l}18.9 \pm 1.8 \\
(32)\end{array}$ & $\begin{array}{l}44.2 \pm 4.4 \\
(32)\end{array}$ & $\begin{array}{l}36.7 \pm 4.2 \\
(32) \S\end{array}$ & $\begin{array}{l}19.5 \pm 2.3 \\
(32) \S\end{array}$ & $\begin{array}{l}18.7 \pm 2.0 \\
(32) \S\end{array}$ \\
\hline Seizures & $\begin{array}{l}458.9 \pm 26.0 \\
(18) \dagger\end{array}$ & $\begin{array}{l}422.6 \pm 26.8 \\
(18) \ddagger\end{array}$ & $\begin{array}{l}22.6 \pm 2.2 \\
(17)\end{array}$ & $\begin{array}{l}18.3 \pm 1.9 \\
(18)\end{array}$ & $\begin{array}{l}42.8 \pm 4.6 \\
(17)\end{array}$ & $\begin{array}{l}34.8 \pm 4.0 \\
(18)\end{array}$ & $\begin{array}{l}19.5 \pm 2.6 \\
(17) \S\end{array}$ & $\begin{array}{l}18.2 \pm 2.3 \\
(18) \S\end{array}$ \\
\hline Group Ib & $\begin{array}{l}460.5 \pm 24.4 \\
(4) \dagger\end{array}$ & $\begin{array}{l}419.1 \pm 12.1 \\
(4)\end{array}$ & $\begin{array}{l}26.6 \pm 1.9 \\
(4)\end{array}$ & $\begin{array}{l}20.1 \pm 1.3 \\
(4)\end{array}$ & $\begin{array}{l}43.6 \pm 0.9 \\
(4)\end{array}$ & $\begin{array}{l}34.2 \pm 1.4 \\
(4)\end{array}$ & $\begin{array}{l}22.2 \pm 0.6 \\
(4) \S\end{array}$ & $\begin{array}{l}20.1 \pm 0.9 \\
(4) \S\end{array}$ \\
\hline Group 2 & $\begin{array}{l}448.6 \pm 14.4 \\
(9)\end{array}$ & $\begin{array}{l}405.6 \pm 16.6 \\
(8)\end{array}$ & $\begin{array}{l}19.7 \pm 1.4 \\
(9)\end{array}$ & $\begin{array}{l}16.5 \pm 1.5 \\
(8)\end{array}$ & $\begin{array}{l}40.2 \pm 2.3 \\
(9) \dagger\end{array}$ & $\begin{array}{l}32.3 \pm 2.7 \\
(8)\end{array}$ & $\begin{array}{l}16.5 \pm 2.3 \\
(9)\end{array}$ & $\begin{array}{l}15.8 \pm 1.3 \\
(8)\end{array}$ \\
\hline Seizures & $\begin{array}{l}461.8 \pm 16.5 \\
(3) \dagger\end{array}$ & $\begin{array}{l}416.9 \pm 21.5 \\
(3)\end{array}$ & $\begin{array}{l}18.5 \pm 1.2 \\
(3) \dagger\end{array}$ & $\begin{array}{l}16.2 \pm 1.8 \\
(3)\end{array}$ & $\begin{array}{l}41.1 \pm 3.8 \\
(3)\end{array}$ & $\begin{array}{l}33.1 \pm 4.4 \\
(3)\end{array}$ & $\begin{array}{l}16.4 \pm 1.5 \\
(3)\end{array}$ & $\begin{array}{l}15.4 \pm 1.2 \\
(3)\end{array}$ \\
\hline Seizures & $\begin{array}{l}457.4 \pm 12.9 \\
(3)\end{array}$ & $\begin{array}{l}412.1 \pm 22.3 \\
(3)\end{array}$ & $\begin{array}{l}21.5 \pm 1.2 \\
(3)\end{array}$ & $\begin{array}{l}17.9 \pm 2.5 \\
(3)\end{array}$ & $\begin{array}{l}42.0 \pm 1.0 \\
(3)\end{array}$ & $\begin{array}{l}32.8 \pm 2.8 \\
\text { (3) }\end{array}$ & $\begin{array}{l}18.4 \pm 0.5 \\
(3)\end{array}$ & $\begin{array}{l}17.7 \pm 1.0 \\
(3) \dagger\end{array}$ \\
\hline No seizures & $\begin{array}{l}433.5 \pm 4.3 \\
(7)\end{array}$ & $\begin{array}{l}370.3 \pm 28.4 \\
(7) \ddagger\end{array}$ & $\begin{array}{l}20.8 \pm 0.8 \\
(7)\end{array}$ & $\begin{array}{l}16.6 \pm 1.3 \\
(7)\end{array}$ & $\begin{array}{l}41.1 \pm 1.1 \\
(7)\end{array}$ & $\begin{array}{l}30.7 \pm 1.4 \\
(7)\end{array}$ & $\begin{array}{l}17.8 \pm 0.8 \\
\text { (7) }\end{array}$ & $\begin{array}{l}16.3 \pm 0.7 \\
\text { (3) }\end{array}$ \\
\hline $\begin{array}{l}\text { Ad libitum oral water } \\
\text { Group } 4 \mathrm{a}\end{array}$ & $\begin{array}{l}438.1 \pm 9.0 \\
(11)\end{array}$ & $\begin{array}{l}403.0 \pm 17.7 \\
(11)\end{array}$ & $\begin{array}{l}21.2 \pm 1.5 \\
(11)\end{array}$ & $\begin{array}{l}17.6 \pm 1.5 \\
(11)\end{array}$ & $\begin{array}{l}44.3 \pm 2.5 \\
(11) \dagger\end{array}$ & $\begin{array}{l}33.4 \pm 2.2 \\
(11)\end{array}$ & $\begin{array}{l}17.6 \pm 1.1 \\
(11)\end{array}$ & $\begin{array}{l}16.8 \pm 1.1 \\
(11) \dagger\end{array}$ \\
\hline Seizures & $\begin{array}{l}452.1 \\
(1)\end{array}$ & $\begin{array}{l}433.6 \\
\text { (1) }\end{array}$ & $\begin{array}{l}20.4 \\
(1)\end{array}$ & $\begin{array}{l}19.0 \\
\text { (1) }\end{array}$ & $\begin{array}{l}42.8 \\
\text { (1) }\end{array}$ & $\begin{array}{l}34.6 \\
(1)\end{array}$ & $\begin{array}{l}16.5 \\
\text { (1) }\end{array}$ & $\begin{array}{l}17.2 \\
(1)\end{array}$ \\
\hline No seizures & $\begin{array}{l}436.7 \pm 8.2 \\
(10)\end{array}$ & $\begin{array}{l}399.0 \pm 15.3 \\
(10)\end{array}$ & $\begin{array}{l}21.3 \pm 1.5 \\
(10)\end{array}$ & $\begin{array}{l}17.4 \pm 1.5 \\
(10)\end{array}$ & $\begin{array}{l}44.4 \pm 2.6 \\
(10) \dagger\end{array}$ & $\begin{array}{l}33.3 \pm 2.3 \\
(10)\end{array}$ & $\begin{array}{l}17.8 \pm 1.1 \\
(10)\end{array}$ & $\begin{array}{l}16.8 \pm 1.1 \\
(10) \dagger\end{array}$ \\
\hline Group 4b & $\begin{array}{l}442.7 \pm 6.0 \\
\text { (6) }\end{array}$ & $\begin{array}{l}406.9 \pm 13.1 \\
(6)\end{array}$ & $\begin{array}{l}21.8 \pm 0.9 \\
(6)\end{array}$ & $\begin{array}{l}19.7 \pm 1.0 \\
(6)\end{array}$ & $\begin{array}{l}41.9 \pm 0.8 \\
(6)\end{array}$ & $\begin{array}{l}35.3 \pm 2.4 \\
(6)\end{array}$ & $\begin{array}{l}19.2 \pm 0.8 \\
(6) \S\end{array}$ & $\begin{array}{l}18.2 \pm 1.0 \\
(6) \S\end{array}$ \\
\hline
\end{tabular}

* All values expressed as mean $\pm 1 \mathrm{SD}$. () indicate number of animals. Water content is expressed in $\mathrm{g} / 100 \mathrm{~g}$ dry weight. $\mathrm{Na}, \mathrm{K}$, and $\mathrm{Cl}$ are expressed as $\mathrm{mEq} / 100 \mathrm{~g}$ dry weight.

$\dagger P<0.05, \ddagger P<0.01$, and $\S P<0.001$ (when compared with normal rabbits). 
seizures. The water content of brain tissue was significantly greater in animals rehydrated intravenously. In each group, the water content of brain tissue was greater in animals that manifested seizure activity than in those which did not. Our data indicate that plasma electrolytes do not reflect the electrolyte and water content of the brain and that brain swelling and relative water intoxication can occur at a time when plasma electrolytes are approaching normal. The increased content of brain water correlates with the clinical signs, seizure activity, and electroencephalographic abnormalities of water intoxication (11). There was no significant difference among groups in the incidence of seizure activity during the intravenous rehydration of hypernatremic animals when evaluated by the rate of administration of the intravenous fluids. There was a trend towards fewer seizures with longer periods of rehydration.

Animals allowed to rehydrate themselves orally tended to drink more in the first $2 \mathrm{~h}$ of rehydration than would have been given intravenously over the same period of time, yet the incidence of seizures was lower. The plasma $\mathrm{Na}$ levels of rabbits rehydrated orally were similar to those of animals in Group 1a at 2 and $4 \mathrm{~h}$ of rehydration (Fig. 3), suggesting that ingested water had been absorbed rapidly. Furthermore, at autopsy, the animals allowed to drink ad libitum had a fluid content in the gastrointestinal tract equal to that of the intravenously rehydrated animals. The only rabbit rehydrated orally that developed seizure activity during rehydration consumed an amount of water during the $10 \mathrm{~h}$ of rehydration before his seizure in excess of that ingested by rabbits that did not develop seizures. The reasons for the excessive intake are unknown because the plasma electrolytes were normal after $4 \mathrm{~h}$ of rehydration.

The data on blood volume in rehydrated animals revealed that the volume of fluid infused did not lead to hypervolemia, but to restoration of a normal level. This correlates with the normal range of the weights of liver and lungs and the absence of edema in tissues. Autopsy examination of all animals with chronically induced hypernatremia revealed no evidence of subdural or subarachnoid hemorrhages. This was at variance with the finding of a high incidence of intracranial hemorrhage in humans (14) and in animals rendered hypernatremic by Luttrell et al. (15).

The mechanism by which animals can rehydrate themselves orally at the same rate, and in some instances with a larger volume of fluid without developing seizure activity, is unclear. Animals allowed to rehydrate themselves orally over a 24-h period had a significantly lower incidence of seizures than those rehydrated intravenously. The manner in which these animals drank and the correlation of the return of plasma sodium concentrations to normal levels is of interest in that an extraordinary volume was consumed within the first $2 \mathrm{~h}$. After $3-4 \mathrm{~h}$, the average rate of ingestion approximated that of normal rabbits (Fig. 3). The plasma $\mathrm{Na}$ and $\mathrm{K}$ values were similar in the orally rehydrated and the intravenously rehydrated groups; however, the incidence of seizures was significantly higher in the animals rehydrated intravenously. At the end of $2 \mathrm{~h}$ into the rehydration period, with plasma $\mathrm{Na}$ concentrations identical in both groups, the plasma osmolality was significantly higher in animals rehydrated intravenously. Interest in the infused glucose and its possible role in the pathogenesis of the seizure activity is stimulated by the observation that plasma glucose levels were significantly higher $(P<0.01)$ at the end of rehydration and in the final samples from animals with seizures (11). Further work needs to be undertaken to define tne potential role of glucose in the production of seizure activity. Other investigators have postulated that fructose, sorbitol, inositol (18), taurine, glutamate, aspartate, and urea $(1,3)$ may accumulate within neural tissue and act as osmotically active materials that may help to reduce seizure activity.

Tolerance to orally administered water is seen in other animal species. Camels who undergo a loss of water corresponding to $30 \%$ of their body weight can drink in 10 min enough water for complete hydration with no clinical manifestations of water intoxication (21). Electrolyte concentrations in serum were not monitored in these camels. Humans of all ages who are strong enough to drink will voluntarily ingest a volume of glucoseelectrolyte solution necessry for both rehydration and maintenance $(8,20)$. In one series, mild to moderately dehydrated children voluntarily drank an average of $18 \mathrm{ml} \cdot \mathrm{kg}^{-1} \cdot \mathrm{h}^{-1}$ (range, 3.4-45.8) over a 3-12-h rehydration period (8). One of these children had hypernatremic dehydration and ingested over 152 $\mathrm{ml} / \mathrm{kg}$ over $12 \mathrm{~h}$ with return of serum sodium values to near normal.

Studies of patients with cholera and non-cholera diarrhea and isotonic dehydration have established the efficacy of oral therapy $(6,8,16,17,19,20)$. Clinical experience with oral therapy of children with hypernatremia is limited but has been successful (8). We have demonstrated success with oral rehydration of rabbits with hypernatremic dehydration and feel clinical trials in children are warranted (9). It should be emphasized that oral rehydration can only be undertaken in a child with stable vital signs. Presently, we are conducting studies to determine the rate and type of solution with regard to electrolyte (5) and carbohydrate (13) content that should be utilized for oral therapy of children with this condition. Answers to these questions will provide the clinician with a better means of treating children with this difficult electrolyte derangement.

\section{REFERENCES AND NOTES}

1. Baxter, C. F. and Ortiz, C. L.: Amino acids and the maintenance of osmotic equilibrium in brain tissue. Life Sci. 5: 2321 (1966).

2. Bruck, E., Abal, G., and Aceto, T.: Therapy of infants with hypertonic dehydration due to diarrhea. Am. J. Dis. Child., 115: 281 (1968).

3. Chan, P. H. and Fishman, R. A.: Elevation of rat brain amino acids, ammonia and idiogenic osmoles induced by hyperosmolality. Brain Res., 161: 293 (1979).

4. Dodge, P. E., Crawford, J., and Probst, J.: Studies in experimental water intoxication. Arch. Neurol., 3: 513 (1960).

5. Finberg, L.: The role of oral electrolyte-glucose solutions in hydration of children-international and domestic aspects. J. Pediatr., 96: 51 (1980)

6. Hirschhorn, N., Cash, R. A., Woodward, W. E., and Spivey, G. R.: Oral fluid therapy of Apache children with acute infectious diarrhea. Lancet, 2: 15 (1972).

7. Hirschhorn, N., Kinzie, J. L., Sachar, D. B., Northrup, R. S., Taylor, J. O., Ahmad, S. Z., and Phillips, R. A.: Decrease in net stool out-put in cholera during intestinal perfusion with glucose containing solutions. N. Engl. J. Med., 279: 176 (1968).

8. Hirschhorn, N. M., McCarty, B. J., Ranney, B., Hirschhorn, M. A., Woodward, S. T., Lacapa, A., Cash, R. A., and Woodward, W. E.: Ad libitum oral glucose-electrolyte therapy for acute diarrhea in Apache children. J. Pediatr., 83: 562 (1973).

9. Hogan, G. R.: Hypernatremia-problems in management. Pediatr. Clin. N. Am., 23: 569 (1976).

10. Hogan, G. R., Dodge, P. R., Gill, S. R., Master, S., and Sotos, J.: Pathogenesis of seizures occurring during restoration of plasma tonicity to normal in animals previously chronically hypernatremic. Pediatrics, 43: 54 (1969).

11. Hogan, G. R., Dodge, P. R., Gill, S., Scholl, M. L., and Master, S.: Electrophysiological response of the rabbit brain to chronic hypernatremic dehydration and rehydration. Pediatrics, 50: 769 (1972).

12. Hogan, G. R., Gill, S. R., Master, S., and Dodge, P. R.: On the pathogenesis of seizures occurring during rehydration in chronic hypertonic dehydration. Trans. Amer. Neurol. Assoc., 90: 257 (1965).

13. Hogan, G. R., Pickering, L. K., Dodge, P. R., Shepard, J. B., and Master, S.: The incidence of seizures following rehydration of hypernatremic rabbits with intravenous glucose or fructose solutions. Pediatr. Res., (Submitted).

14. Luttrell, C. N. and Finberg, L.: Hemorrhagic encephalopathy induced by hypernatremia. I. Clinical, laboratory and pathological observations. Arch. Neurol. Psychol., 81: 424 (1959).

15. Luttrell, C. N., Finberg, L., and Drawdy, L.: Hemorrhagic encephalopathy induced by hypernatremia. Il. Experimental observations of hyperosomlarity in cats. Arch. Neurol., 1: 153 (1959).

16. Nalin, D. R., Cash, R. A., and Rahman, M.: Oral (or nasogastric) maintenance therapy for cholera patients in all groups. Bull. World Hlth. Organ., 43: 361 (1970).

17. Pierce, N. F., Banwell, J. G., Mitra, R. C., Caranasos, G. J., Keimozitz, R. I., Mondal, A., and Manji, P. M.: Effect of intragastric glucose electrolyteinfusion upon water and electrolyte balance in Asiatic cholera. Gastroenterology, 55: 333 (1968).

18. Prockop, L. D.: Hyperglycemia, polyol accumulation, and increased intracranial pressure. Arch. Neurol., 25: 126 (1971).

19. Sack, D. A., Islam, S., Brown, K. H., Islam, A., Kabir, A. K. M. I., Chowdhury, 
A. M. A. K., and Ali, M. A.: Oral therapy in children with cholera: A comparison of sucrose and glucose electrolyte solutions. J. Pediatr., 96: 20 (1980).

20. Sack, R. B., Pierce, N., and Hirschhorn, N.: The current status of oral therapy in the treatment of acute diarrhea illness. Am. J. Clin. Nutr., 31: 2251 (1978).

21. Schmidt-Neilsen, B., Schmidt-Neilsen, K., Houpt, T. R., and Jarnum, S. A. Water balance of the camel. Am. J. Physiol., 185: 185 (1956).

22. Sotos, J. F., Dodge, P. R., Meara, P., and Talbot, N.: Studies in experimental hypertonicity: I. Pathogenesis of the clinical syndrome, biochemical abnormalities and causes of death. Pediatrics, 26: 925 (1960).

23. Zissa, F. and Reeve, E. B.: Erroneous measurement of plasma volume in the rabbit by T-1824. Am. J. Physiol., 194: 522 (1958).
24. The present address of Dr. Philip R. Dodge, Department of Pediatrics, Washington University School of Medicine, 500 South Kingshighway, St. Louis, Missouri 63178.

25. The present address of Dr. Larry K. Pickering, Department of Pediatrics, Program in Infectious Diseases, University of Texas Medical School, 6431 Fannin Street, Houston, Texas, 77030.

26. Requests for reprints should be addressed to: Dr. Gwendolyn R. Hogan, Department of Neurology, Louisiana State University School of Medicine, 1501 Kings Highway, Shreveport, Louisiana 71103.

27. Received for publication November 24, 1981.

28. Accepted for publication July $1,1983$.

\title{
Resistance of the Male Gonad to a High Galactose Diet
}

\author{
Y. T. CHEN, ${ }^{(26)}$ D. R. MATTISON, B. B. BERCU, AND J. D. SCHULMAN
}

Laboratory of Developmental Pharmacology, [Y.T.C.] and the Pregnancy Research Branch [D.R.M., B.B.B.], National Institute of Child Health and Human Development, National Institutes of Health, Bethesda, Maryland and Depatment of Obstetrics and Gynecology [J.D.S.], Pediatrics and Genetics, George Washington University

Washington, D.C., USA

\section{Summary}

Rats were fed a $50 \%$ galactose diet during pregnancy and nursing, and the testes were later examined and hormone levels determined in male offspring. Exposure to galactose for various periods during pregnancy, throughout the entire gestation, or postnatally to nursing mother until pups were 5 wk of age produced no significant differences from control testicular weight, seminiferous tubular diameter, or microscopic appearance of the testis when the offspring became adult (66 or 127 d). Serum leuteinizing hormone, follicle stimulating hormone, and testosterone levels were determined $127 \mathrm{~d}$ postnatally and no significant differences from controls were observed in any of the treatment groups. Blood glactose-1-phosphate levels in animals receiving the $50 \%$ galactose diet were comparable to levels observed in human galactosemia. The resistance of the rat testis to a high galactose diet is consistent with the infrequency of testicular insufficiency in human galactosemia, and contrasts with the prenatal female gonadal sensitivity to galactose previously demonstrated in the rat and the high frequency of ovarian failure in human galactosemia.

\section{Abbreviations}

FSH, follicle stimulating hormone gal-1-p, galactose-1-phosphate LH, luteinizing hormone

With early diagnosis through newborn screening programs and institution of appropriate treatment, many patients with inherited metabolic disorders have survived with good long-term health and are now reaching childbearing age. Individuals with some inborn errors of metabolism have borne children (17), but their long-term fertility is largely unstudied.
Galactosemia, secondary to a deficiency in galactose-1-phosphate uridyl-transferase activity is inherited as an autosomal recessive trait and is characterized by mental retardation, cataracts, hepatosplenomegaly, and renal tubular dysfunction (19). The frequent association between this form of galactosemia and premature ovarian failure, even when a galactose-restricted diet is started early in infancy, is well documented $(9,11,21)$. Endocrinologic studies in affected women are consistent with hypergonadotropic hypogonadism. In contrast, testicular dysfunction is uncommon in galactosemia. Kaufman et al. (11) studied eight male patients, and found no evidence of hypothalamic, pituitary or testicular dysfunction. Steinman et al. (21), however, reported elevated levels of basal and stimulated FSH in three of their older patients (age, 21-24-yr-old), suggesting an abnormality in seminiferous tubular function.

Administration to rats of a $30-50 \%$ galactose diet is known to produce cataracts, liver abnormalities, and aminoaciduria resembling the human galactosemia syndrome $(18,20)$. We have shown previously, using this animal model, that offspring of rats fed a high galactose diet during pregnancy have significantly reduced numbers of oocytes (1). The data suggests that prenatal toxicity from galactose and/or its metabolites may contribute to the premature ovarian failure characteristic of human galactosemia. In this paper, we report, using the same animal model and similar experimental design, the effect of galactose treatment on male reproductive function.

\section{MATERIALS AND METHODS}

Galactose, gal-1-p, galactose dehydrogenase, and alkaline phosphate were purchased from Sigma Chemical Co. (St. Louis, $\mathrm{MO}$ ), and a $50 \%$ galactose diet and corresponding regular rodent diet without galactose (NIH-07) from Zeigler Bros., Inc. (Gardners, PA). NIH-07 regular rodent diet consits of $24.5 \%$ protein, $5.2 \%$ fat, $3.7 \%$ fiber, and approximately $50 \%$ carbohydrate. The 